\title{
ESTUDIO EXPERIMENTAL SOBRE LA VIABILIDAD DEL INJERTO LIBRE DE EPITELIO URINARIO AUTÓLOGO CULTIVADO IN VITRO
}

\author{
E. DE DIEGO RODRÍGUEZ, A. VILLANUEVA PEÑA, A. ROCA EDREIRA*, B. MARTÍN \\ GARCÍA*, A. MEANA INFIESTA***, SARA GÓMEZ LLAMES***, J. GÓMEZ ROMÁN** \\ Servicio de Urología. Hospital Comarcal de Laredo. Cantabria. *Servicio de Urología. \\ **Servicio de Anatomía Patológica. Hospital Universitario Marqués de Valdecilla. Santander. Cantabria. \\ ${ }^{* * *}$ Centro Comunitario de Sangre y Tejidos del Principado de Asturias. Oviedo.
}

Actas Urol Esp. 28 (10): 714-731, 2004

\section{RESUMEN \\ ESTUDIO EXPERIMENTAL SOBRE LA VIABILIDAD DEL INJERTO LIBRE DE EPITELIO URINARIO AUTÓLOGO CULTIVADO IN VITRO}

OBJETIVO: Con el presente trabajo pretendimos aplicar las técnicas de cultivo in vitro de queratinocitos así como los principios de la ingeniería tisular al epitelio urinario, con el fin de conseguir un tejido autólogo tridimensional apto para trasplantar, y confirmar a su vez la viabilidad del injerto libre del mismo en un modelo experimental.

MATERIAL Y METODOS: Se procedió a un diseño experimental en el animal de laboratorio donde se aplicaron las técnicas del cultivo celular y de la ingeniería de tejidos. Se obtuvieron muestras de mucosa vesical de conejo, las cuales fueron cultivadas in vitro, implantándose posteriormente el tejido obtenido en cada animal, estableciéndose 3 grupos, con diferentes periodos de seguimiento ( 7,14 y 30 días), para proceder al estudio histomorfológico de la viabilidad de dichos implantes.

RESULTADOS: Se obtuvo un tejido tridimensional compuesto por una submucosa bioartificial a base de un gel de fibrina y fibroblastos, sobre la que descansan las células uroepiteliales, utilizando una malla de ácido poliglicólico, la cual facilitó la manipulación del tejido y el posterior injerto del mismo. Todos los implantes resultaron viables y se pudo comprobar como los injertos con mayor periodo de seguimiento (30 días) se encontraban mejor conformados, con múltiples capas celulares.

CONCLUSIONES: Las técnicas de cultivo in vitro de queratinocitos son aplicables a otros epitelios, entre ellos el urinario. En un periodo de tiempo relativamente corto se puede obtener un tejido in vitro tridimensional apto para trasplantar. El estudio histológico puso de manifiesto que el injerto libre de epitelio urinario autólogo cultivado es totalmente viable, apuntando futuras aplicaciones clínicas.

PALABRAS CLAVE: Cultivo in vitro. Urotelio. Ingeniería tisular. Implante.

\section{ABSTRACT \\ EXPERIMENTAL STUDY ABOUT VIABILITY OF AUTOLOGOUS FREE GRAFT IN VITRO CULTIVATED URINARY EPITHELIUM}

OBJETIVE: The purpose of this study is to apply the in vitro keratinocyte culture techniques and the tissue engineering principles to urothelium, to obtain a three-dimensional autologous tissue suitable for grafting. We also showed the viability of free graft cultured urothelium in an experimental model.

MATERIAL AND METHODS: An animal experimental model was designed to apply the techniques of cellular culture and tissue engineering.

Biopsy specimens of bladder mucosa were obtained, in vitro cultured and posteriorly implanted in each animal. We established three groups based on different follow-up periods ( 7,14 and 30 days), and made a final histomorphological study to demonstrate the viability of the graft at the end of its respective follow-up period.

RESULTS: A three-dimensional in vitro tissue was obtained, composed of a bio-artificial submucosa (fibrin gel and fibroblast) where the uroepithelial cells were seeding; a biodegradable polyglycolic acid mesh was used to facilitate the tissue manipulation and implantation.

In the morphological study all the implants appeared viable, but the grafts with longer implantations periods were better conformed, showing a tisular structure with multiple cellular layers.

CONCLUSIONS: In vitro keratinocyte culture techniques could be applied to other epithelial tissues as the urothelium. We obtained a three-dimensional in vitro tissue suitable for grafting in a relatively short time.

The histological study demonstrated that free autologous urothelial graft is totally viable, opening future clinics applications.

KEY WORDS: In vitro culture. Urothelium. Tissue engineering. Implant. 
D esde hace muchos años uno de los principales retos de la medicina ha sido el hecho de poder mantener, restaurar o mejorar la función de órganos o tejidos dañados o perdidos en la anatomía humana.

A partir de 1950 se comienzan a desarrollar una serie de técnicas de laboratorio que permiten que las células una vez extraídas del órgano o tejido que las produce, puedan sobrevivir y multiplicarse reproduciendo las condiciones físicas y ambientales adecuadas para ello.

En 1975 Rheinwald y Grenn ${ }^{1}$ establecen las condiciones idóneas para cultivar indefinidamente queratinocitos, siendo teóricamente posible aplicar dichas técnicas a otros epitelios diferentes al cutáneo. En 1980 Banks-Schelegel ${ }^{2}$ demuestra la viabilidad como injerto libre del epitelio obtenido in vitro en el animal de experimentación. Posteriormente autores como Shoutgate ${ }^{3}$, De Luca $^{4}, \mathrm{Ueda}^{5}$ o $\mathrm{Hata}^{6}$, aplican esta metodología para la obtención de epitelio de la cavidad bucal.

Pese al enorme interés suscitado por estas técnicas en la década de los 70 , el urotelio no parecía, al menos inicialmente, el tejido más apto para su aplicación.

Autores como Elliot ${ }^{7}$, Chlapowski ${ }^{8}$, Pauli ${ }^{9}$ o Messing ${ }^{10}$, intentan el cultivo in vitro de urotelio no neoplásico, encontrando importantes dificultades en la recolección celular, contaminación de los medios por células estromales, escaso potencial de crecimiento y pobre capacidad de diferenciación.

Reznikoff ${ }^{11}$ y Schmit ${ }^{12}$ perfeccionan los métodos de recolección celular así como los medios y las condiciones de cultivo, obteniendo monocapas de células uroteliales, sin conseguir un tejido útil para trasplantar.

En 1990 Romagnoli ${ }^{13,14}$ aplica las técnicas introducidas por Rheinwald y Green ${ }^{1}$ al epitelio uretral, obteniendo un tejido autólogo que posteriormente utiliza para el tratamiento de hipospadias complejos en niños, con buenos resultados.

En 1992 Atala $^{15,16}$ aplica los principios de la ingeniería tisular ${ }^{17-20}$ (campo interdisciplinario que aplica los principios de la ingeniería y biología celular hacia el desarrollo de sustitutos biológicos que restauren, mantengan o mejoren la función de órganos y tejidos dañados) al urotelio, obteniendo células uroteliales aisladas que culti- va y siembra sobre polímeros sintéticos biodegradables obteniendo así un material útil para su trasplante.

Por último en 1995, Fujiyama ${ }^{21}$ realiza una reconstrucción tridimensional de mucosa vesical, diseñando una submucosa bioartificial compuesta por un gel de colágeno y fibroblastos, sobre la cual siembra las células uroteliales previamente recolectadas.

A su vez, en base a la experiencia del cultivo de queratinocitos sobre matrices de fibrina, autores como Wechselberger ${ }^{22-24}$, Schoeller ${ }^{25-27}$, Schaefer ${ }^{28}$ o $\mathrm{Bach}^{29}$, consiguen cultivar in vitro células uroepiteliales sobre dichas matrices, constituyendo la fibrina un soporte adecuado para el desarrollo y diferenciación de las células.

El aparato génito-urinario está expuesto a un gran número de posibles lesiones ya desde el inicio de su desarrollo embrionario, que hagan necesaria la reconstrucción del mismo por lo que la cirugía reconstructiva génito-urinaria se enfrenta en no pocas ocasiones a la falta de tejidos urológicos nativos para tal fin, requiriendo el uso de tejidos heterólogos o materiales sintéticos con no siempre buenos resultados y con conocidas complicaciones ${ }^{30-32}$.

Por tanto sería deseable el poder disponer de un tejido autólogo en cantidad suficiente como para paliar las serias complicaciones a las que el urólogo se enfrenta en la reconstrucción del aparato urinario ${ }^{33-35}$.

En nuestro trabajo, basado en la experiencia de los investigadores, aplicamos las técnicas del cultivo celular y de la ingeniería de tejidos para la creación in vitro de un tejido urológico autólogo tridimensional útil para trasplantar. Nuestro objetivo fue diseñar un modelo experimental en el animal de laboratorio donde pudiésemos aplicar las técnicas del cultivo celular al urotelio y demostrar a su vez la viabilidad del injerto libre de epitelio urinario autólogo cultivado.

\section{MATERIAL Y MÉTODOS}

\section{ANIMAL DE EXPERIMENTACIÓN}

Como animal de laboratorio se utilizó el conejo blanco de Nueva Zelanda, macho o hembra indistintamente, de peso aproximado entre 3 y 4,5 $\mathrm{Kg}$.

Al extraer las muestras del propio animal obtendríamos un tejido autólogo, lo que nos per- 
mitió establecer un modelo experimental en un animal inmunológicamente intacto.

\section{MÉTODOS}

\section{HIPÓTESIS DE TRABAJO}

Se pretende crear un modelo experimental en el animal de laboratorio para la aplicación de las técnicas de cultivo celular in vitro al epitelio urinario, creando una mucosa tridimensional y demostrando posteriormente su viabilidad como injerto libre autólogo.

Se combinan los principios del cultivo celular dotando a las células cultivadas de una lámina propia bioartificial, con los de la ingeniería tisular, aprovechando las características de los polímeros biodegradables ${ }^{36,37}$ sirviendo de soporte al tejido cultivado para su posterior implantación.

\section{DISEÑO EXPERIMENTAL}

Se seleccionaron 15 conejos estableciéndose 3 grupos: (Tabla 1).

GRUPO I: $(n=5)$ A estos animales se les extrajo un fragmento de mucosa vesical, de la que se obtienen 2 muestras, una para su estudio como control y otra para ser cultivada.

El epitelio obtenido por cultivo in vitro fue implantado como injerto libre en el dorso del animal del que se había obtenido, aplicando el método descrito por Barrandon ${ }^{38}$ en ratones atímicos con epitelio cultivado humano.

El seguimiento que se realizó en este grupo tras el implante fue de 1 semana.

GRUPO II: $(n=5)$ A estos animales se les aplicó el mismo procedimiento que a los del grupo I, implantándoles la muestra de epitelio cultivado también en el lomo del animal.

\section{Tabla 1}

Procedimientso realizados en los diferentes grupos

\begin{tabular}{ccccc} 
In & $\begin{array}{c}\text { Extracción } \\
\text { muestra }\end{array}$ & $\begin{array}{c}\text { Cultivo } \\
\text { in vitro } \\
\text { muestra }\end{array}$ & $\begin{array}{c}\text { Implante } \\
\text { tejido } \\
\text { cultivado }\end{array}$ & \\
\hline $\begin{array}{c}\text { GRUPO } 1 \\
(\mathrm{n}=5)\end{array}$ & $\sqrt{ }$ & $\sqrt{ }$ & $\sqrt{ }$ & 7 dias \\
\hline $\begin{array}{c}\text { GRUPO } 2 \\
(\mathrm{n}=5)\end{array}$ & $\sqrt{ }$ & $\sqrt{ }$ & $\sqrt{ }$ & 14 dias \\
\hline $\begin{array}{c}\text { GRUPO 3 } \\
(\mathrm{n}=5)\end{array}$ & $\sqrt{ }$ & $\sqrt{ }$ & $\sqrt{ }$ & 30 dias \\
\hline
\end{tabular}

El periodo de seguimiento en este grupo fue de 2 semanas.

GRUPO III: $(n=5)$ A los conejos de este grupo se les practicó la misma técnica que en los grupos I y II, realizando un seguimiento del implante en cada animal de 4 semanas en este caso.

A todos los animales se les realizó estudio bacteriológico de una muestra de orina, desestimándose los casos positivos.

\section{TÉCNICA ANESTÉSICA}

Todos los animales fueron anestesiados utilizando una mezcla de 2 fármacos: clorhidrato de tiazina (Rompúm ${ }^{\circledR}$, Bayer AG, Levercusen. Alemania.) y ketamina (Ketolar ${ }^{\circledR}$ 50, Parke-Davis, Warner Lambert. USA.), por vía intramuscular, calculando las dosis según el peso del animal; si ésta no permitiese la intervención se administra $1 / 4$ de la dosis de inicio.

\section{TÉCNICA QUIRÚRGICA}

Extracción de biopsia de mucosa vesical

Se procedió a la realización de una cistotomía, obteniendo así una muestra de mucosa vesical de cada animal, de tamaño no superior a $1 \mathrm{~cm}^{2}$ (Fig. 1).

El fragmento de mucosa vesical se recoge en medio de cultivo estéril, siendo válido en principio cualquier medio.

Tras la realización de una meticulosa hemostasia se procedió a cistorrafia por planos utilizando sutura discontinua de ácido poliglicólico de 5 y 4/0 respectivamente. Acto seguido se completó el cierre de la pared abdominal también con sutura reabsorbible de 3 ó 4/0. En ningún caso se colocó sonda vesical tras la intervención.

\section{Injerto en el dorso del animal}

Una vez obtenido el epitelio cultivado se procedió a su implante como injerto libre en el dorso del animal. Se escogió esta zona para evitar posibles autolesiones del implante. Se utilizó el método descrito por Barrandon ${ }^{38}$ en ratones atímicos, con alguna pequeña modificación (Fig. 2).

Se practicó un colgajo cuadrangular de piel completa de $2,5 \times 2,5 \mathrm{~cm}$ que se eleva sobre su eje transverso. En el lecho del colgajo creado se insertó una lámina de silicona estéril $\left(\right.$ Xomed $^{\circledR}$, Jacksonville, FL 32216 USA). 

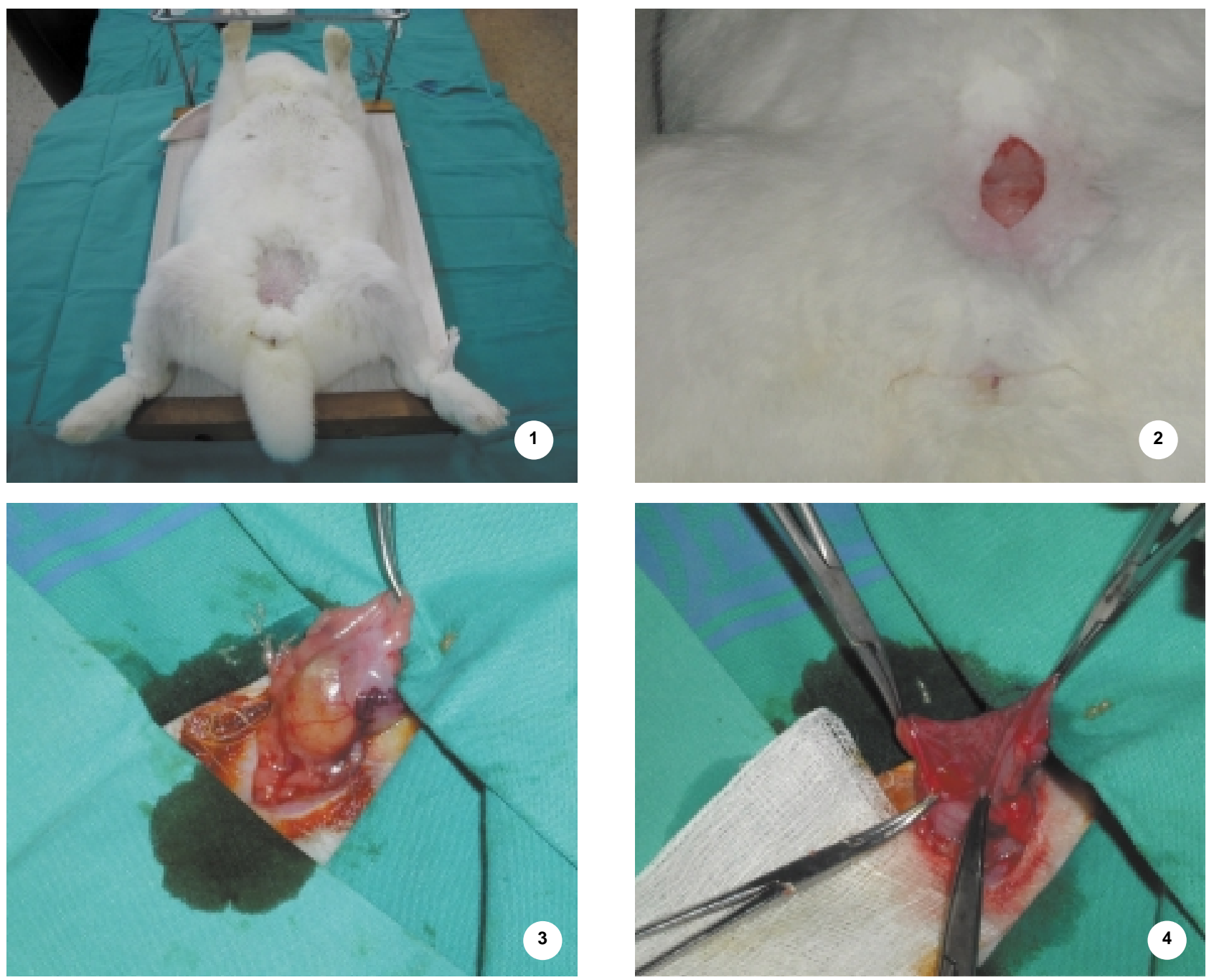

FIGURA 1. 1. Posición del conejo; 2. Incisión suprapúbica; 3. Exposición de la vejiga; 4. Cistotomía.

Posteriormente se evertió el colgajo cutáneo sobre estas estructuras, cerrando la incisión con sutura discontinua de ácido poliglicólico de 4/0, quedando fijado de esta forma el injerto a la cara interna del colgajo.

\section{Extracción-biopsia del injerto}

Transcurridos los periodos de seguimiento previstos en cada grupo se procedió a la extracción de los implantes para el estudio de su viabilidad.

Inicialmente los animales fueron anestesiados según la pauta establecida; se procedió a la elevación del colgajo previamente creado para su estudio macroscópico y posteriormente se extirpó el implante completo para su evaluación microscópica.

\section{CULTIVO IN VITRO DE MUCOSA VESICAL DE CONEJO}

Procesamiento de la muestra

A la llegada de la biopsia de pared vesical al laboratorio se procede a la retirada del medio de transporte, (medio Eagle modificado de Dulbecco (DMEM) suplementado con antibióticos). Con ayuda de una pipeta se depositó la muestra sobre una placa de Petri para proceder a su lavado con solución de tripsina/ácido etilendiaminotetracético (tripsina/EDTA) estéril. Esta solución consta de 0,05 g de tripsina y 0,02 de EDTA disueltos en $100 \mathrm{ml}$ de suero fetal bovino, sin calcio ni magnesio y esterilizado por filtración.

Se trocea finamente la mucosa hasta obtener pequeños fragmentos de tejido uroepitelial, con 

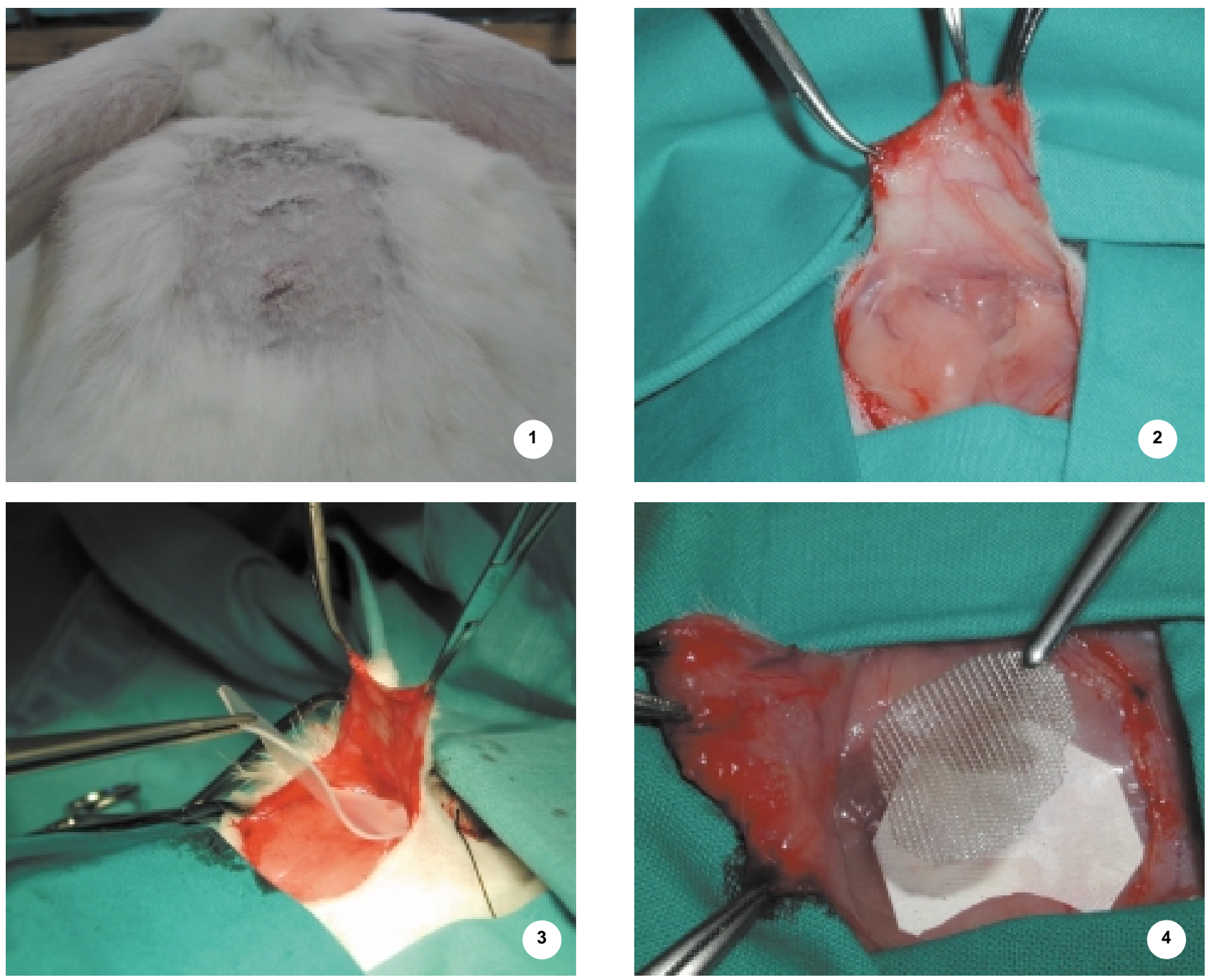

FIGURA 2. 1. Zona rasurada en dorso; 2. Elevación de colgajo; 3. y 4. Inserción lámina silicona en lecho del colgajo.

ayuda de una pipeta previamente empapada de tripsina/EDTA se pasa la muestra a un frasco con agitador magnético estéril, añadiéndose aproximadamente $50 \mathrm{ml}$ de solución de tripsina/EDTA y se incuba a $37^{\circ} \mathrm{C}$, bajo agitación, durante 30 minutos.

Con la ayuda de una pipeta empapada en tripsina /EDTA se procedió a la agitación de los fragmentos de mucosa, dejándose decantar éstos y con cuidado se recogió la tripsina pasándose a un tubo cónico de $15 \mathrm{ml}$. Se añaden $25 \mathrm{ml}$ más de tripsina fresca al frasco agitador que contiene los fragmentos de mucosa y se incuba nuevamente a $37^{\circ} \mathrm{C}$ durante 30 minutos.

La tripsina recogida se neutraliza con igual cantidad de medio de cultivo suplementado con un $10 \%$ de suero fetal bovino y se centrifuga a 1.400 r.p.m. durante 10 minutos. El pellet obtenido se resuspende en $2-3 \mathrm{ml}$ de medio de cultivo $\mathrm{y}$ se procede al recuento celular obtenido en cada incubación con ayuda de una cámara de Neubauer.

El procedimiento se repitió hasta que no se obtuvieron más células de la muestra suspendiéndose entonces las incubaciones.

\section{CULTIVO PRIMARIO DE CÉLULAS UROEPITELIALES}

De las células obtenidas en el procesamiento de la muestra se seleccionan aproximadamente la mitad de ellas para su siembra en un pocillo de cultivo celular de $6 \mathrm{~cm}^{2}$ de superficie en presen- 
cia de una capa alimentadora de $5 \times 10^{5}$ células 3T3 (fibroblastos de ratón irradiados letalmente (6.000 rads), ECACC 85022108), lo que equivale a unas $8 \times 10^{4}$ células $3 \mathrm{~T} 3 / \mathrm{cm}^{2}$.

Para la siembra celular se utilizó medio de cultivo para queratinocitos, cuya composición es a base de medio Eagle modificado de Dulbecco (DMEM) (Biochrom KG) y Ham F-12 (Biochrom $\mathrm{KG}$ ) en proporción 3:1, suplementado con $10 \%$ de suero fetal bovino (Biochrom $\mathrm{KG}$ ), $5 \mu / \mathrm{ml}$ de insulina (Sigma), $0,4 \mu / \mathrm{ml}$ de hidrocortisona (Sigma), 1,3 ng/ml de triyodotironina (Sigma), 8 $\mathrm{ng} / \mathrm{ml}$ de toxina colérica (Sigma) y $24 \mu / \mathrm{ml}$ de adenina (Sigma).

Las células epiteliales sembradas en este medio se mantienen en incubación en estufa de $\mathrm{CO}_{2}$ al $5 \%$ a $37^{\circ} \mathrm{C}$.

El medio de cultivo se reemplaza cada 72 horas; en el primer cambio se añadió al medio 10 $\mathrm{ng} / \mathrm{ml}$ de factor de crecimiento epidérmico (EGF) (Austral Biologicals), repitiéndose la misma operación hasta que las células estuviesen próximas a la confluencia.

Cuando las células epiteliales fueron confluentes se trataron con tripsina/EDTA estéril para despegar las mismas de la superficie del frasco de cultivo.

Una vez individualizadas las células se neutraliza la tripsina mediante la adicción volumen a volumen de medio de cultivo suplementado con un $10 \%$ de suero fetal bovino y se centrifugan a 1.400 r.p.m. durante 10 minutos.

\section{ELABORACIÓN DE LA SUBMUCOSA ARTIFICIAL \\ Cultivo primario de fibroblastos}

Para el cultivo primario de fibroblastos se utilizaron la otra mitad de las células obtenidas inicialmente en el procesamiento de la muestra; en un principio se sembraron aproximadamente $10^{5}$ células en un pocillo de cultivo celular de $6 \mathrm{~cm}^{2}$, en ausencia de células cebadoras 3T3.

Como medio de cultivo se utilizó DMEM suplementado con un $10 \%$ de suero fetal bovino. Los cultivos se mantuvieron en estufa de $\mathrm{CO}_{2}$ al $5 \%$ a $37^{\circ} \mathrm{C}$.

\section{Obtención del gel de fibrina-fibroblastos}

La fuente de fibrina se obtuvo a partir de plasma del propio animal. Muestras de sangre veno- sa previamente extraídas de los conejos fueron centrifugadas a 3.000 r.p.m durante 10 minutos. Se retira del tubo la fracción del plasma, procurando no extraer los hematíes y se congela para su posterior uso.

Los geles para una placa de $66 \mathrm{~cm}^{2}$ de superficie se prepararon con:

- $5 \mathrm{ml}$ de plasma de conejo.

- 800-1200 fibroblastos $/ \mathrm{cm}^{2}$.

- 0,66 mg/ml de ácido tranexámico (Amchafibrin $^{\circledR}$, Fides-Rottapharm).

- $1 \mathrm{ml}$ de cloruro cálcico (Sigma) al $1 \%$ en suero fisiológico.

- Se completa con suero fisiológico hasta un volumen de $15 \mathrm{ml}$.

La mezcla se depositó en la estufa a $37^{\circ} \mathrm{C}$ con un $5 \%$ de $\mathrm{CO}_{2}$ entre 30 minutos y una hora para permitir el secado y coagulación de los geles; transcurrido este tiempo se añadió $10 \mathrm{ml}$ de medio de cultivo para queratinocitos sin EGF.

Para mejorar la consistencia y manipulación del tejido obtenido se utilizó una malla de poliglactin 910 (Vicril $^{\circledR}$ Jhonson \& Jhonson, Intl. Brussels, Belgium), la cual se coloca en una placa de Petri y sobre ella se deposita el gel esperando 24 horas hasta la realización del cultivo secundario.

\section{Cultivo secundario de células uroepiteliales} sobre submucosa artificial

Las células obtenidas en cultivo primario son lavadas con tripsina /EDTA estéril e incubadas a $37^{\circ} \mathrm{C}$ hasta conseguir que las células se despeguen, posteriormente se neutraliza la tripsina mediante la adicción volumen a volumen de medio de cultivo para queratinocitos. Se procede centrifugación a 1.400 r.p.m. y el pellet obtenido se resuspende en 5-10 ml de medio de cultivo de queratinocitos sin EGF.

Las células así obtenidas se siembran sobre la submucosa artificial transcurridas 24 horas de la elaboración de la misma, en ausencia de capa alimentadora de células 3T3. El medio de cultivo se cambió cada 72 horas y el control del cultivo se realizó mediante microscopio de luz invertida.

La estructura del tejido bioartificial obtenido constaba de una capa de células uroepiteliales que descansan sobre una submucosa compuesta de gel de colágeno y fibroblastos sobre una malla de ácido poliglicólico para aportar consistencia (Fig. 3). 


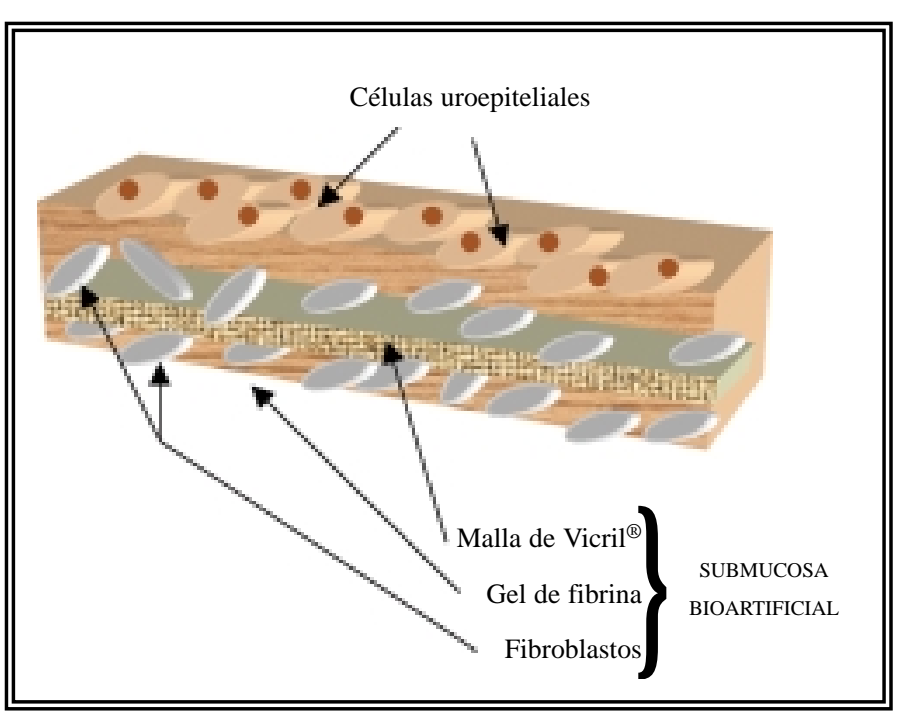

FIGURA 3. Esquema de la estructura tridimensional del tejido obtenido in vitro.

Las células uroepiteliales sembradas sobre la submucosa bioartificial se mantienen en cultivo hasta alcanzar la confluencia.

Todo el procedimiento se resume en la Fig. 4.

Preparación de la lamina para trasplante

A las 24-48 horas de alcanzar las células la confluencia se procedió a la preparación de la lámina para su posterior injerto.

La manipulación de la lámina no plantea dificultad alguna debido a la consistencia aportada por la malla de ácido poliglicólico. El punto clave es conservar la orientación de la lámina de tal forma que la capa epitelial siempre quede en la parte superior para colocarla correctamente a la hora de realizar el injerto, quedando la capa basal del epitelio en contacto con el lecho receptor.

Para mantener la orientación se realizan diferentes cortes a la malla, con formas distintas para así conservar la orientación inicial de las células (Fig. 5).

Una vez preparada la lámina se coloca en un tubo de $50 \mathrm{ml}$ con DMEM enrollada sobre si misma y a temperatura ambiente se puede proceder a su traslado al quirófano para su injerto.

\section{ESTUDIO ANÁTOMO-PATOLÓGICO}

\section{Histología convencional}

Se tomaron inicialmente muestras de mucosa vesical de conejo para su estudio como control; éstas junto con el tejido obtenido in vitro y las muestras recogidas tras los periodos de injerto establecidos fueron depositadas en formol al 10\% para su conservación.

Tras su fijación las muestras fueron sometidas al procesamiento habitual para ser incluidas en parafina y posteriormente teñidas con la técnica de hematoxilina-eosina.

\section{Inmunohistoquímica}

Las tinciones inmunohistoquímicas se realizaron mediante el sistema EnVision, utilizando un inmunoteñidor automático TechMate TM 500-520 (Biotech Solutions, Santa Bárbara, California, USA). Los reactivos se obtuvieron del kit de DAKO EnVision TM + System, Peroxidase (DBA) (Glostrup. Dinamarca).

En nuestro caso se realizó estudio inmunohistoquímico en las muestras practicadas de mucosa vesical de conejo normal, del tejido obtenido in vitro y de los injertos de dicho tejido tras los periodos de observación establecidos.

Utilizamos los siguientes anticuerpos: Anticuerpo monoclonal Panqueratina (CK 22) $\left(\mathrm{DAKO}^{\circledR}\right.$ Glostrup. Dinamarca), Anticuerpo monoclonal colágeno IV (C IV) (DAKO ${ }^{\circledR}$ Glostrup. Dinamarca), Anticuerpo monoclonal laminina. (DAKO ${ }^{\circledR}$ Glostrup. Dinamarca).

\section{RESULTADOS}

\section{CULTIVO IN VITRO DE MUCOSA VESICAL DE} CONEJO

\section{Recolección celular}

En todos los casos se practicó el mismo procesamiento de la muestra, obteniéndose un número variable e impredecible de células viables, sin encontrarse factores determinantes en la consecución de una mayor o menor cantidad de células disgregadas, tratándose de muestras de tamaño similar (Tabla 2).

En cualquier caso, de todas las biopsias procesadas se pudo obtener un número suficiente de células epiteliales como para permitir su expansión en cultivo primario.

Inicialmente sembramos unas 25.000 células epiteliales por $\mathrm{cm}^{2}$; en todos los cultivos se pudo apreciar una gran rapidez en el crecimiento de las células uroepiteliales de conejo, muy superior 


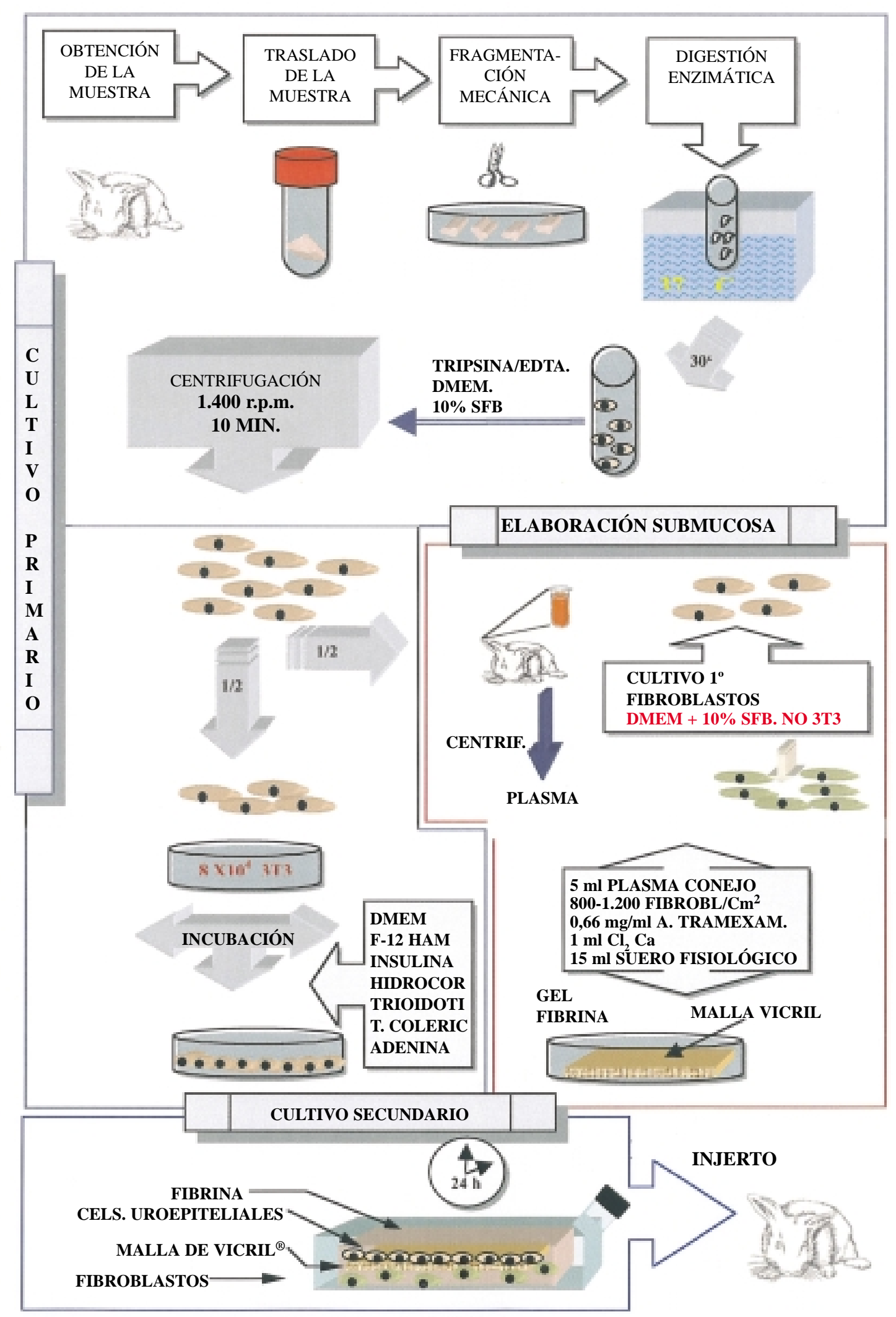

FIGURA 4. Metodologia del cultivo in vitro de mucosa vesical de conejo. 

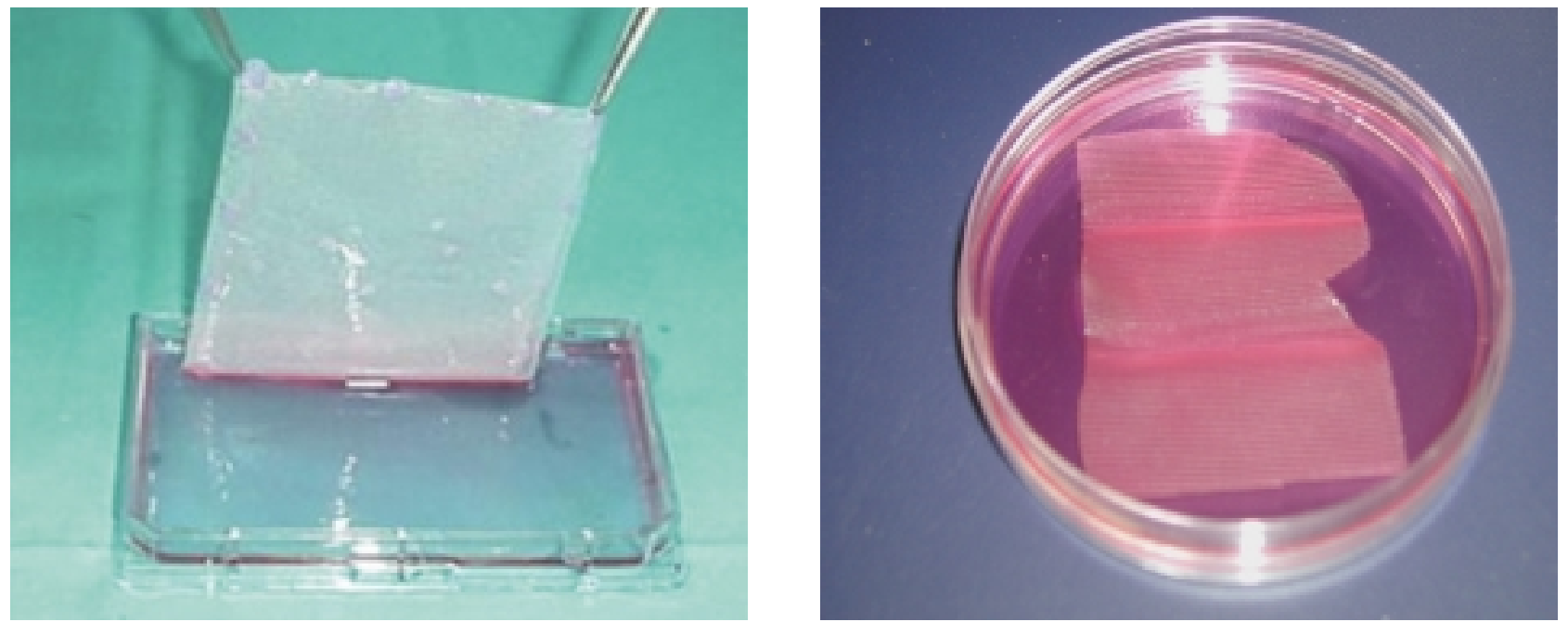

FIGURA 5. Orientación de las láminas para injerto.

Tabla 2

Resultados recolección celular, cultivo primario y secundario de urotelio de conejo

\begin{tabular}{|c|c|c|c|c|c|c|c|}
\hline \multirow{2}{*}{ Muestra } & \multirow{2}{*}{$\begin{array}{l}\text { Número } \\
\text { Células } \\
\text { obtenidas }\end{array}$} & \multicolumn{2}{|c|}{ Cultivo primario } & \multirow{2}{*}{$\begin{array}{c}\text { Fibroblastos } \\
\text { Células } \\
\text { cultivadas }\end{array}$} & \multicolumn{3}{|c|}{ Cultivo secundario } \\
\hline & & $\begin{array}{l}\text { Células } \\
\text { cultivadas }\end{array}$ & $\begin{array}{c}\text { Días } \\
\text { cultivo }\end{array}$ & & $\begin{array}{l}\text { Días } \\
\text { cultivo }\end{array}$ & $\begin{array}{l}\text { Total días } \\
\text { cultivo }\end{array}$ & Viabilidad \\
\hline $\mathrm{M}_{1}$ & 180.000 & 100.000 & 10 & 80.000 & 11 & 21 & $\sqrt{ }$ \\
\hline $\mathrm{M}_{2}$ & 195.000 & 100.000 & 11 & 95.000 & 11 & 22 & $\sqrt{ }$ \\
\hline $\mathrm{M}_{3}$ & 280.000 & 160.000 & 10 & 120.000 & 12 & 22 & $\sqrt{ }$ \\
\hline $\mathrm{M}_{4}$ & 110.000 & 50.000 & 12 & 60.000 & 11 & 23 & $\sqrt{ }$ \\
\hline $\mathrm{M}_{5}$ & 650.000 & 325.000 & 10 & 325.000 & 10 & 20 & $\sqrt{ }$ \\
\hline $\mathrm{M}_{6}$ & 708.750 & 354.300 & 11 & 354.000 & 10 & 21 & $\sqrt{ }$ \\
\hline $\mathrm{M}_{7}$ & 1.200 .000 & 600.000 & 11 & 600.000 & 11 & 22 & $\sqrt{ }$ \\
\hline $\mathrm{M}_{8}$ & 830.000 & 415.000 & 10 & 415.000 & 10 & 20 & $\sqrt{ }$ \\
\hline $\mathrm{M}_{9}$ & 950.000 & 475.000 & 10 & 475.000 & 13 & 23 & $\sqrt{ }$ \\
\hline $\mathrm{M}_{10}$ & 2.625 .000 & 1.300 .000 & 11 & 1.300 .000 & 11 & 22 & $\sqrt{ }$ \\
\hline $\mathrm{M}_{11}$ & 780.000 & 390.000 & 10 & 390.000 & 11 & 21 & $\sqrt{ }$ \\
\hline $\mathrm{M}_{12}$ & 1.500 .000 & 750.000 & 12 & 750.000 & 10 & 22 & $\sqrt{ }$ \\
\hline $\mathrm{M}_{13}$ & 400.000 & 200.000 & 11 & 200.000 & 11 & 22 & $\sqrt{ }$ \\
\hline $\mathrm{M}_{14}$ & 2.350 .000 & 1.175 .000 & 12 & 1.175 .000 & 11 & 23 & $\sqrt{ }$ \\
\hline $\mathbf{M}_{15}$ & 550.000 & 225.000 & 10 & 225.000 & 10 & 20 & $\sqrt{ }$ \\
\hline
\end{tabular}

al crecimiento de queratinocitos en las mismas condiciones de cultivo, de forma tal que en muestras sucesivas (a partir de la muestra número 5) se destinaron la mitad de las células obtenidas en el procesamiento de la biopsia para cultivo primario de fibroblastos y la otra mitad para cultivo primario de células uroepiteliales.

\section{CULTIVO PRIMARIO DE CELULAS UROEPITELIALES}

A los 3-4 días de cultivo fue posible comprobar el inicio de formación de colonias de células epiteliales en todos los frascos de cultivo, no obstante aún era mayoritaria la presencia de células alimentadoras 3T3. 

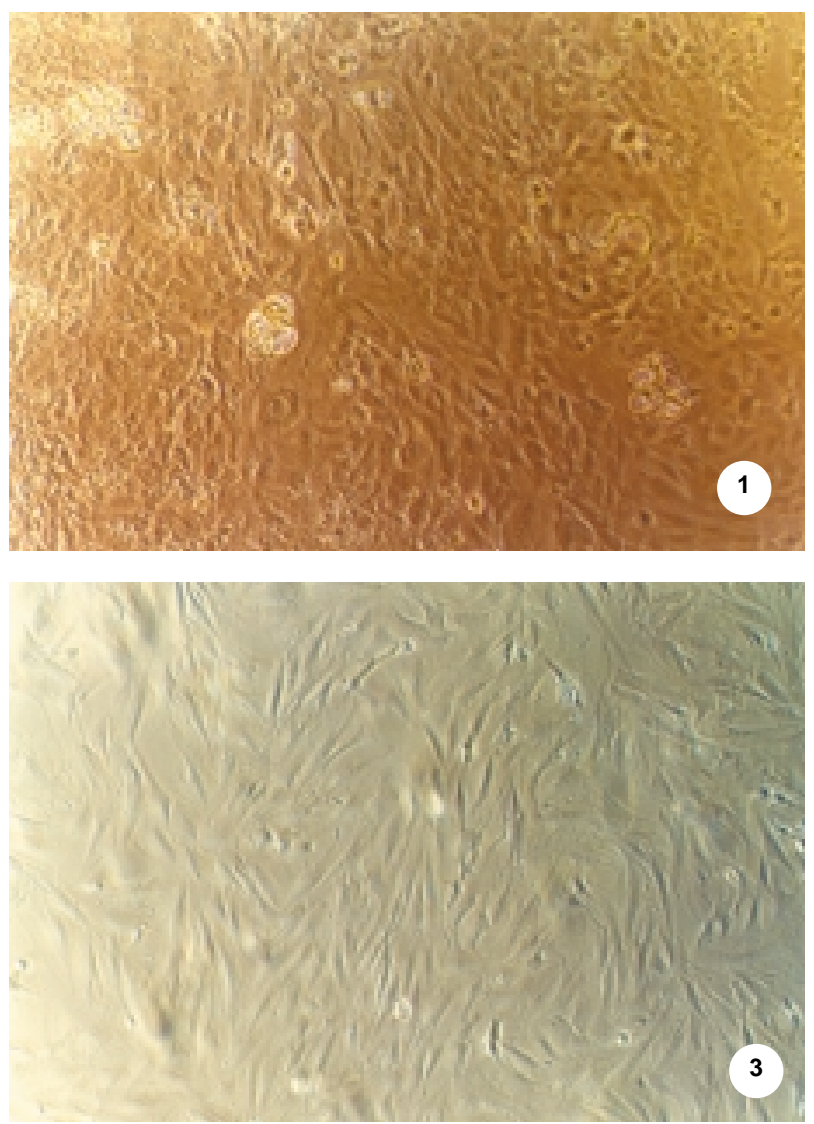

FIGURA 6. 1. y 2. Cultivo primario de células uroepiteliales. $100 x$; 3. y 4. Cultivo primario de fibroblastos, $100 x$.

A partir de la primera semana se puso de manifiesto el rechazo de los fibroblastos 3T3 a la periferia, a medida que el crecimiento de las células uroepiteliales era predominante, disminuyendo considerablemente su número, de forma tal que en el momento de alcanzarse la confluencia celular no fue posible observar células 3T3 (Fig. 6.1 y 6.2).

Los cultivos primarios de células epiteliales fueron confluentes en un plazo mínimo de 10 días y máximo de 12 .

En ninguno de los cultivos se planteó problemas de crecimiento celular, contaminación fúngica o bacteriana o desestructuración de los cultivos.

\section{CULTIVO SECUNDARIO SOBRE GEL DE FIBRINA-FIBROBLASTOS \\ Elaboración del gel de fibrina-fibroblastos}

Todos los geles se elaboraron con plasma procedente del animal de experimentación mediante la centrifugación de muestras de sangre venosa extraídas previamente.
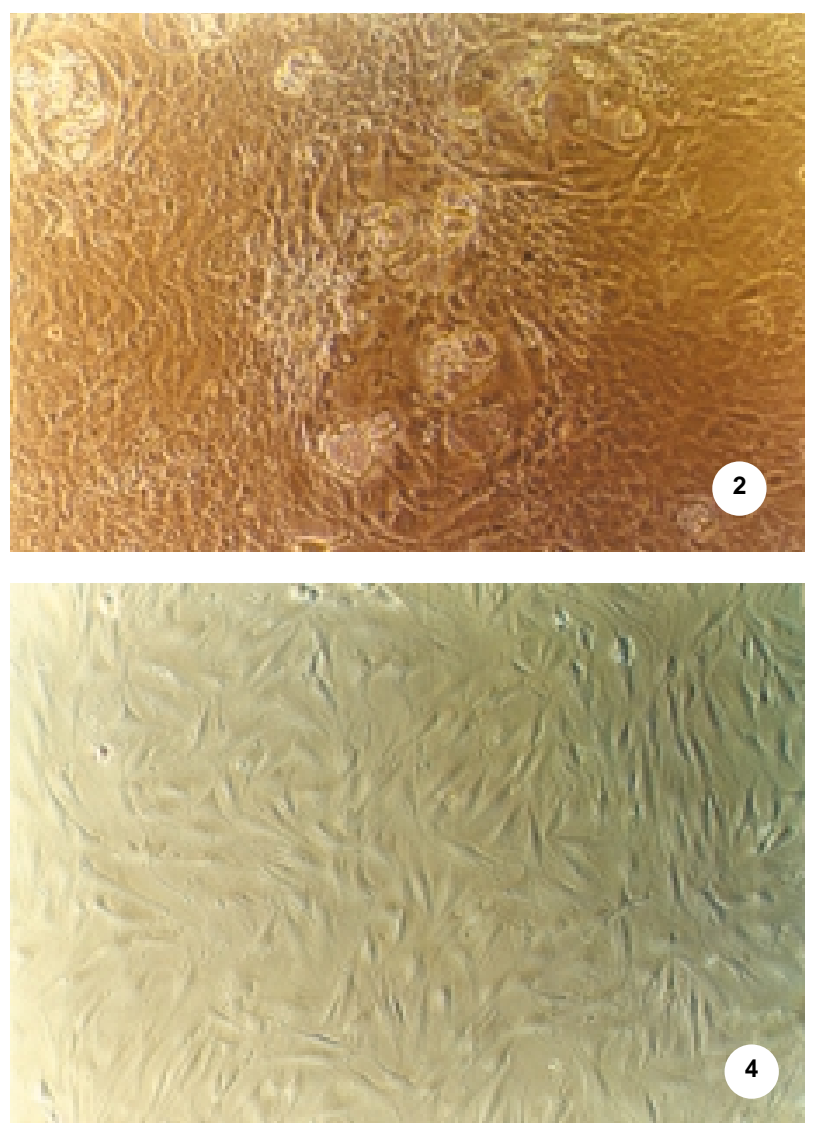

Los fibroblastos fueron obtenidos del cultivo primario de aproximadamente la mitad de las células conseguidas en el procesamiento inicial de la muestra, utilizando medio de cultivo adecuado para permitir únicamente el desarrollo y crecimiento de fibroblastos.

No hubo problemas de crecimiento ni de contaminación de los fibroblastos en cultivo primario (Fig. 6.3 y 6.4).

En la elaboración de la submucosa de la muestra número 4 surgieron complicaciones probablemente originadas por la obtención de una cantidad insuficiente de fibrina al procesar la muestra de plasma obtenida de ese conejo. Estos hechos provocaron dificultades en la obtención del gel, lo que a su vez complicó el cultivo secundario, obligándonos a repetir el proceso.

\section{CULTIVO SECUNDARIO SOBRE SUBMUCOSA}

\section{ARTIFICIAL}

Cuando se alcanzó la confluencia del cultivo primario de las células uroteliales (entre 10 y 13 
días) y 24 horas después de haber confeccionado la submucosa sobre una malla de ácido poliglicólico para dar consistencia y facilitar la manipulación del tejido obtenido, se procedió al cultivo secundario de las células sobre dicha estructura.

De esta forma el tejido bioartificial diseñado constaba de una capa submucosa configurada por el gel de fibrina y fibroblastos y la malla de Vicril ${ }^{\circledR}$, y sobre ésta las células epiteliales sembradas.

La confluencia celular en cultivo secundario se alcanzó en un plazo de 10 y 13 días, de forma tal que el tiempo necesario para la obtención de una mucosa bioartificial tridimensional completa osciló entre 20 y 23 días (Tabla 2).

En ninguno de los cultivos realizados sobre gel de fibrina se pudo apreciar retracción significativa del tejido de tal manera que la superficie ini- cialmente cultivada era la obtenida como uroepitelio completo.

\section{ESTUDIO INMUNOHISTOLOGICO PREVIO AL INJERTO}

\section{Histología convencional}

Las muestras de mucosa vesical de conejo obtenidas para su estudio como control constan histológicamente de un revestimiento epitelial de 5 a 6 células de espesor, en las que se puede distinguir más o menos claramente una capa superficial de células de gran tamaño, de citoplasma amplio y eosinófilo, una capa intermedia con células de menor tamaño y citoplasma claro y una capa de células basales, de pequeño tamaño y núcleos grandes (Fig. 7.1).

$\mathrm{El}$ tejido cultivado previo al injerto presentaba el aspecto de una lamina translúcida de mínimo

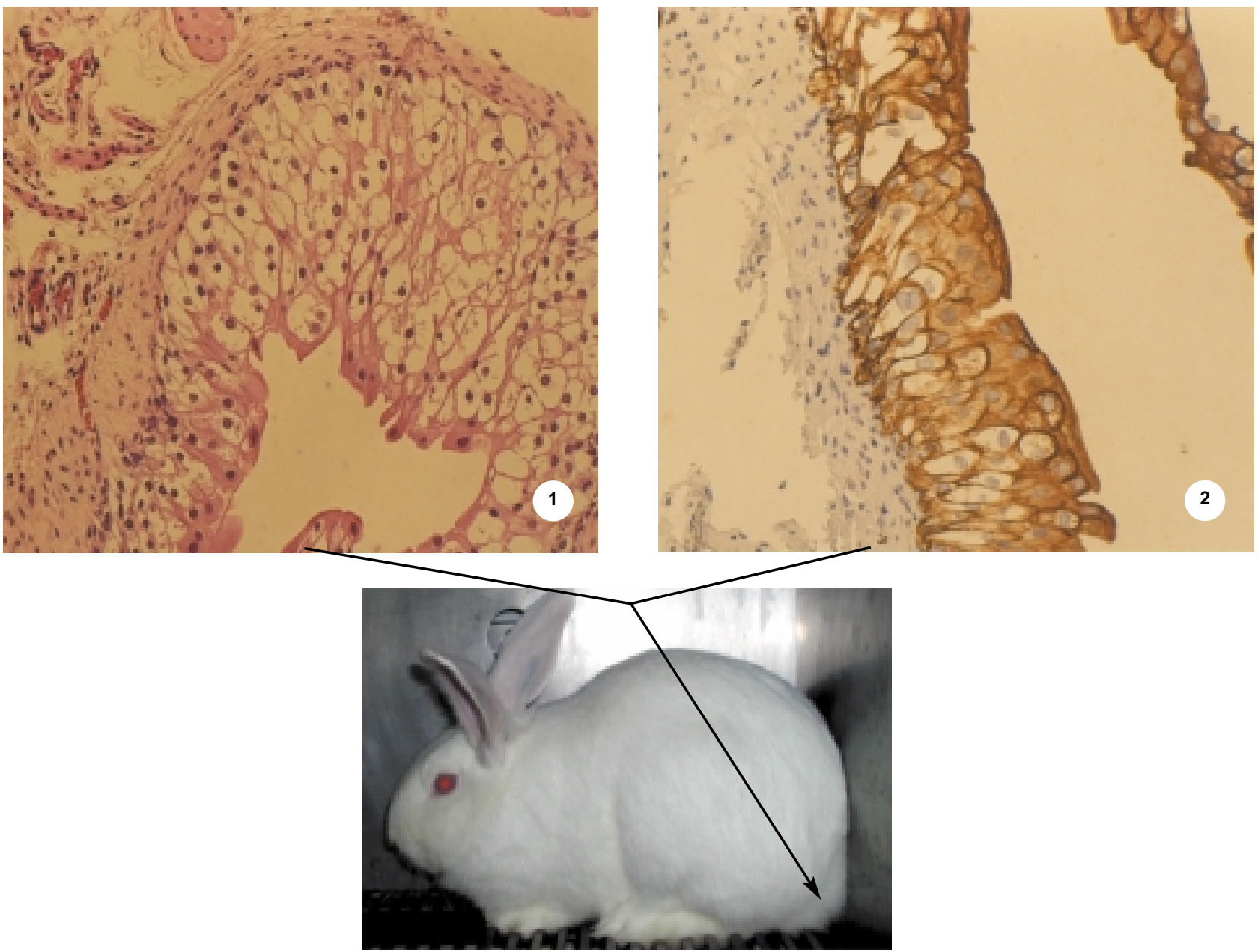

FIGURA 7. 1. Vejiga in vivo de conejo. H. E. $10 x ; 2$. Vejiga in vivo de conejo. Citoqueratina. $10 x$. 
espesor, morfológicamente constituido por una capa eosinofilica homogénea y acelular, de espesor aproximado de $10 \mu$, sobre la que descansa una capa de células de estirpe epitelial (Fig. 8).

\section{Inmunohistoquímica}

En los diferentes estratos celulares de la mucosa vesical de los conejos se pudo apreciar una fuerte reactividad a citoqueratinas en las células superficiales; la inmunotinción de las células intermedias para citoqueratinas resultó más débil que la capa anterior y en cuanto a las células basales se apreció una reactividad bastante irregular (Fig. 7.2).

Se realizó inmunotinción con anticuerpos monoclonales frente a colágeno IV y laminina, presentes en la membrana basal de los epitelios, resultando negativos en todos los casos de mucosa vesical de conejo in vivo.

En el tejido obtenido en cultivo previo al injerto se evidenció una débil tinción frente a citoqueratinas y negativa para colágeno IV y laminina.

\section{Injerto del urotelio cultivado en el animal de experimentación}

Se practicaron 15 injertos en los correspondientes animales de los que se obtuvieron la muestra de mucosa vesical para su cultivo.

Todos los animales toleraron el procedimiento sin problema alguno, dada su sencillez.

No se demostró en ningún caso signos macroscópicos de rechazo o infección del injerto libre.

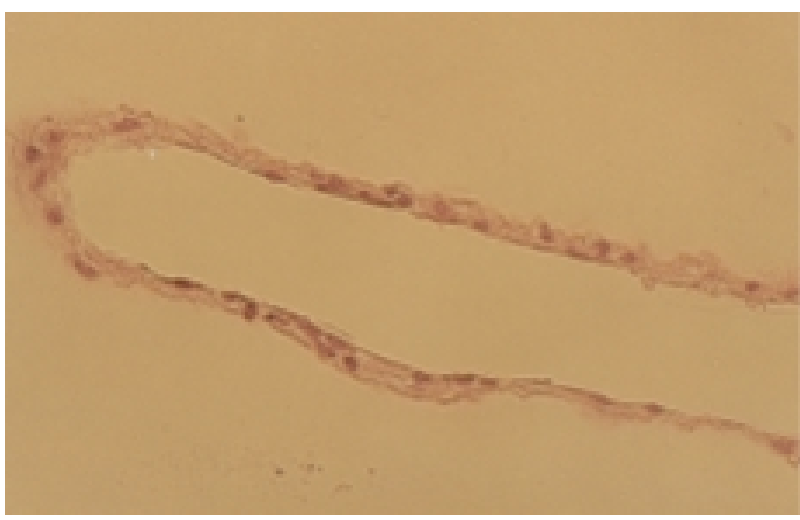

FIGURA 8 Uroepitelio in vitro. H.E. $10 x$..

\section{ESTUDIO INMUNOHISTOLÓGICO TRAS EL INJERTO}

\section{Aspecto macroscópico}

$\mathrm{El}$ aspecto macroscópico que presentaban los injertos al elevarlos sobre su eje transversal fue bastante similar en los diferentes grupos y periodos de injerto.

Se podía apreciar como dato más llamativo, la presencia de zonas más engrosadas y blanquecinas en el dorso de los colgajos, más evidentes en los injertos de un mes de seguimiento, que atribuimos como el tejido cultivado (Fig.9).

Morfología de los diferentes injertos (Fig. 10).

Injertos de una semana: En estos tejidos se aprecia una intensa reacción granulomatosa, sobre la que se observa una lámina eosinofilica continua, homogénea y acelular, con un infiltrado inflamatorio rico en eosinófilos, de intensidad leve.
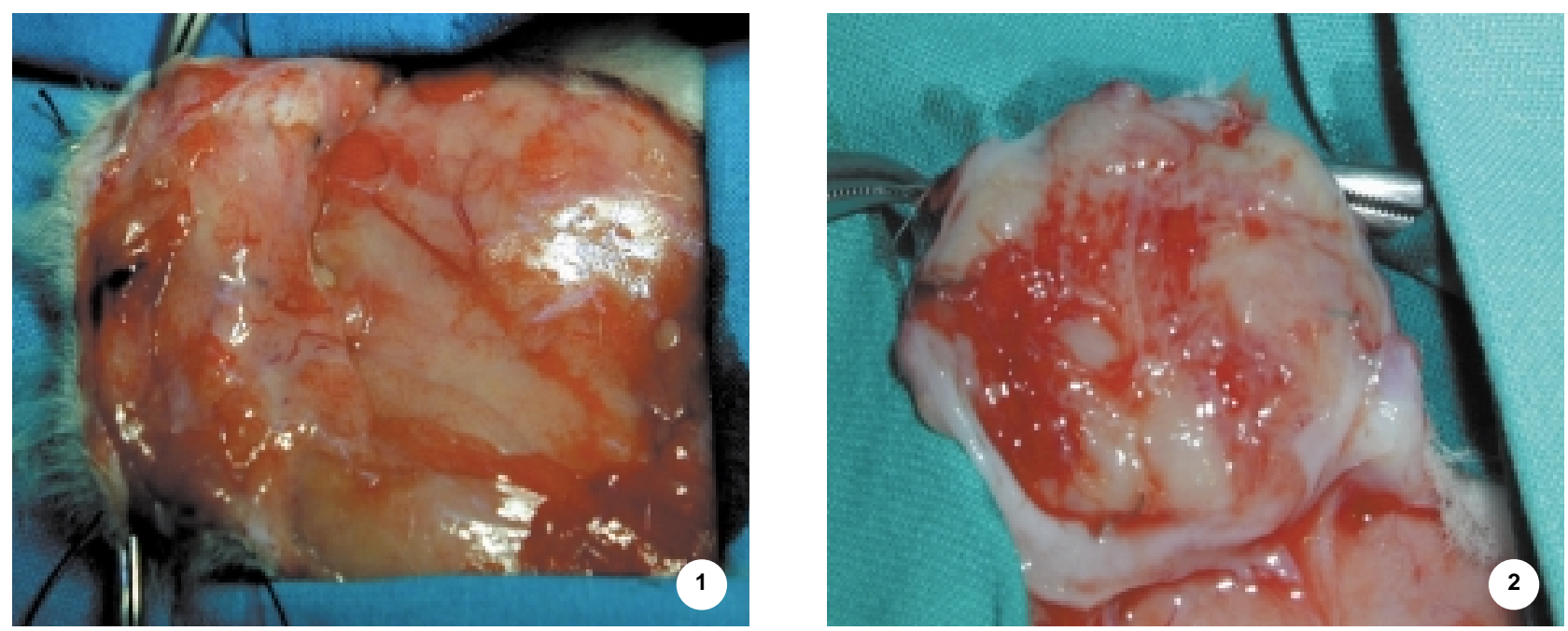

FIGURA 9. 1. Aspecto macroscópico injerto 1 semana; 2. Aspecto macroscópico injerto 4 semanas. 


\section{HISTOMORFOLOGÍA INJ ERTOS 1 SEMANA}
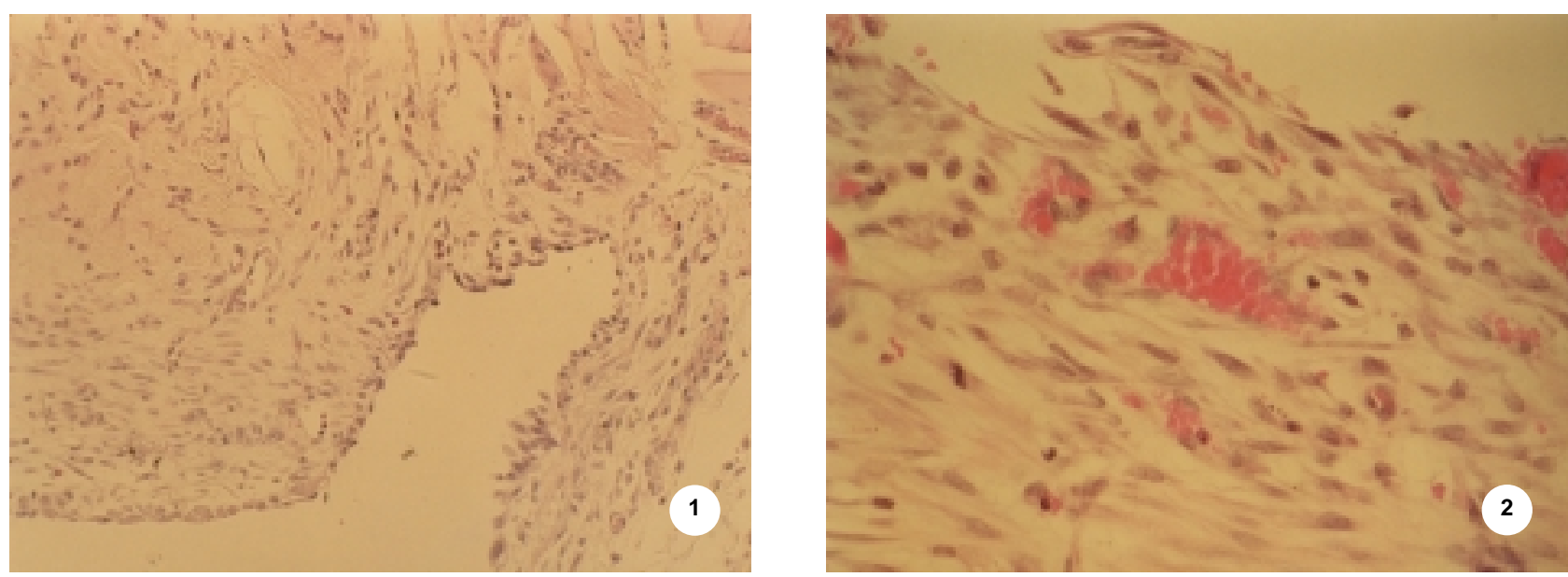

HISTOMORFOLOGÍA INJ ERTOS 2 SEMANAS
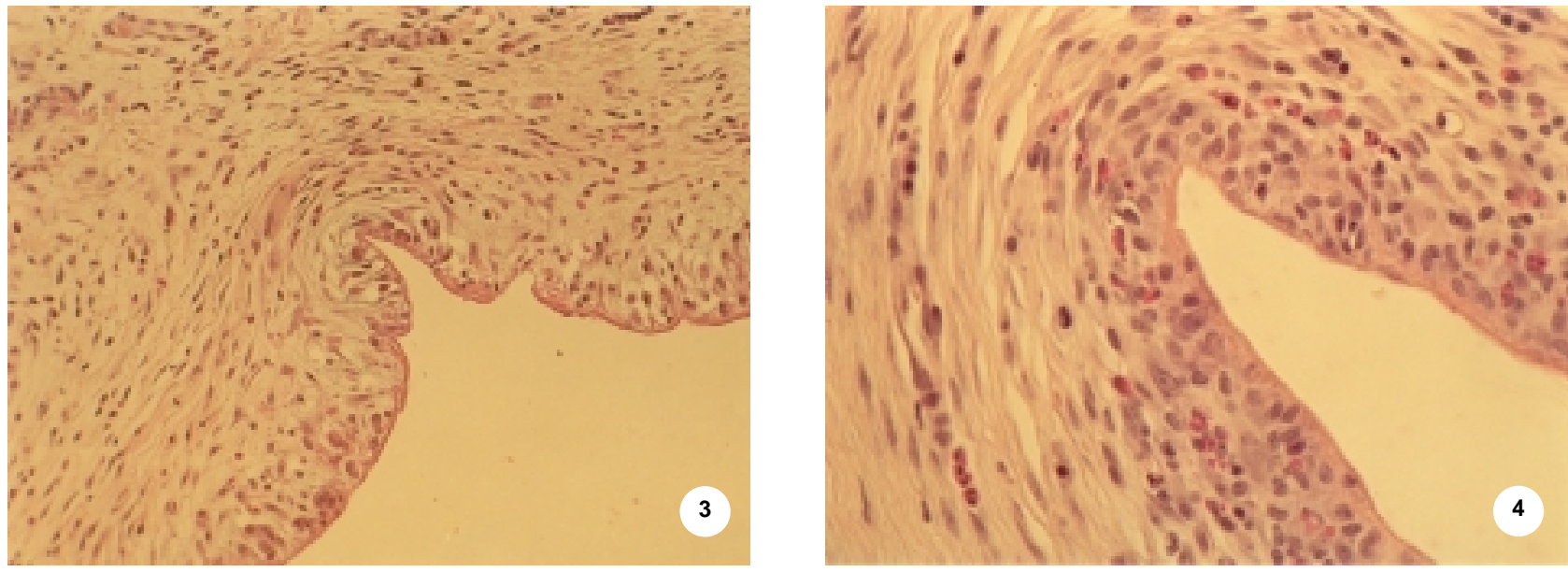

\section{HISTOMORFOLOGÍA INJ ERTOS 4 SEMANAS}
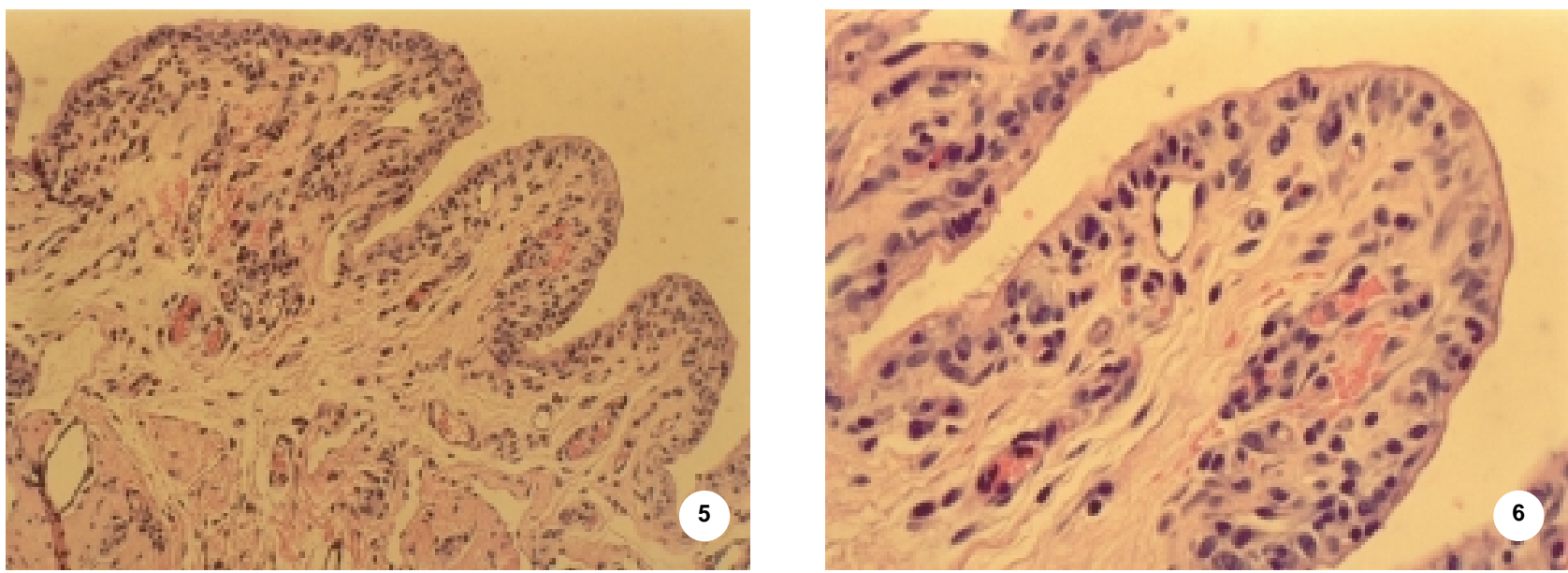

FIGURA 10. 1. y 2. Injerto 1 semana. H.E. $10 x$ y $25 x$; 3. y 4. Injerto 2 semanas. H. E. $10 x$ y $25 x$; 5 . y 6 . Injerto 2 semanas. H. E. $10 x \boldsymbol{y} 25 x$. 
Existe un revestimiento epitelial de células basales, discontinuo de 1 ó 2 capas de espesor (Fig. 10.1 y 10.2).

En esta fase se aprecia una escasa respuesta fibrosa.

Injertos de dos semanas: Se observa igualmente una reacción granulomatosa a cuerpo extraño y un intenso infiltrado inflamatorio, con predominio de eosinófilos.

No se observa de forma clara la lámina eosinofílica, pero sí es patente y llamativo el revestimiento epitelial, que ya es más continuo y presenta hasta 3 y 4 capas de espesor (Fig. 10.3 y 10.4).

Injertos de cuatro semanas: Las características morfológicas son similares a los implantes de dos semanas; siendo aún más patente el revestimien- to epitelial de varias capas de grosor, una menor respuesta inflamatoria y un mayor grado de fibrosis (Fig. 10.5 y 10.6).

\section{Inmunohistoquímica (Fig. 11)}

En los implantes de una semana se observó una tinción muy débil para citoqueratinas en la capa de células uroepiteliales discontinua que se apreció en las muestras (Fig. 11.1).

De igual forma no se pudo demostrar la presencia de una membrana basal; la estructura eosinofílica observada no reaccionó frente a colágeno IV ni frente a laminina.

En los injertos de dos semanas de seguimiento se pudo evidenciar una mayor positividad de las células epiteliales a citoqueratinas y además también resultaron positivas a ellas una pobla-
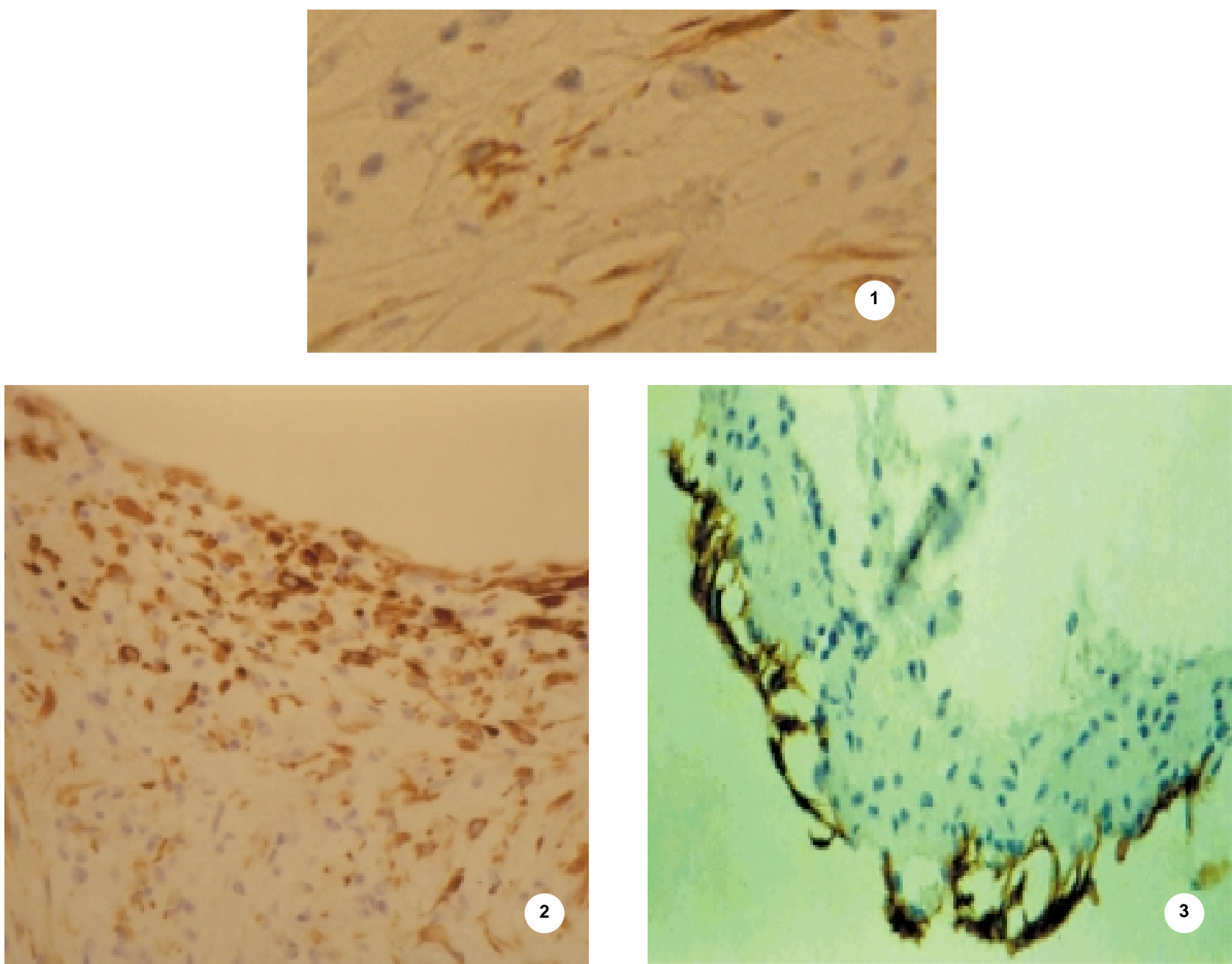

FIGURA 11. 1. Injerto 1 semana. Citoqueratina. $10 x$; 2 . Injerto 2 semanas. Citoqueratina. $10 x$; 3 . Injerto 4 semanas. Citoqueratina. $10 x$. 
ción de células inmaduras, de morfología fusiforme que se encuentran inmersas en el tejido subepitelial (Fig 11.2).

No se pudo apreciar tinción de colágeno IV o laminina en ninguna estructura.

En los implantes de cuatro semanas de evolución se observó el mismo comportamiento que en el grupo anterior, siendo manifiesta la positividad para citoqueratinas de las células de revestimiento y de igual forma, no identificándose ninguna estructura positiva para laminina o colágeno IV (Fig 11.3).

Es evidente por tanto, el origen epitelial de las células de revestimiento como demuestra la positividad para citoqueratinas en los tejidos obtenidos, observándose una mayor intensidad en la tinción en los periodos de injerto más largos, al madurar las células basales que son las inicialmente predominantes.

$\mathrm{Ni}$ en el urotelio in vivo de conejo, ni el obtenido in vitro, ni tampoco en los tejidos tras el injerto fue posible demostrar la presencia de membrana basal mediante la inmunotinción con anticuerpos anti-colágeno IV o laminina.

Al comparar los resultados obtenidos en los diferentes periodos de los implantes y las características histomorfológicas de los mismos, (Fig. 12) se aprecia cómo los epitelios con mayor tiempo de injerto se encuentran mejor conformados, con varias capas celulares, pudiéndose incluso apreciar la adquisición de cierto grado de diferenciación y maduración por parte de las células, las cuales son predominantemente de tipo basal en los tejidos obtenidos in vitro así como en los periodos iniciales de injerto, para ir adquiriendo un aspecto de células más maduras y con mayor reacción a citoqueratinas.

\section{DISCUSIÓN}

A pesar del enorme interés suscitado en la década de los 70 con la aparición de las nuevas técnicas para el cultivo in vitro de los epitelios, el urotelio no parecía, al menos inicialmente, el tejido idóneo para su aplicación.

Los primeros pasos en el cultivo in vitro de células uroteliales no neoplásicas mostraron importantes limitaciones para una correcta recolección celular, frecuente contaminación de los cultivos por células estromales y un escaso

\section{INJ ERTOS 1 SEMANA}

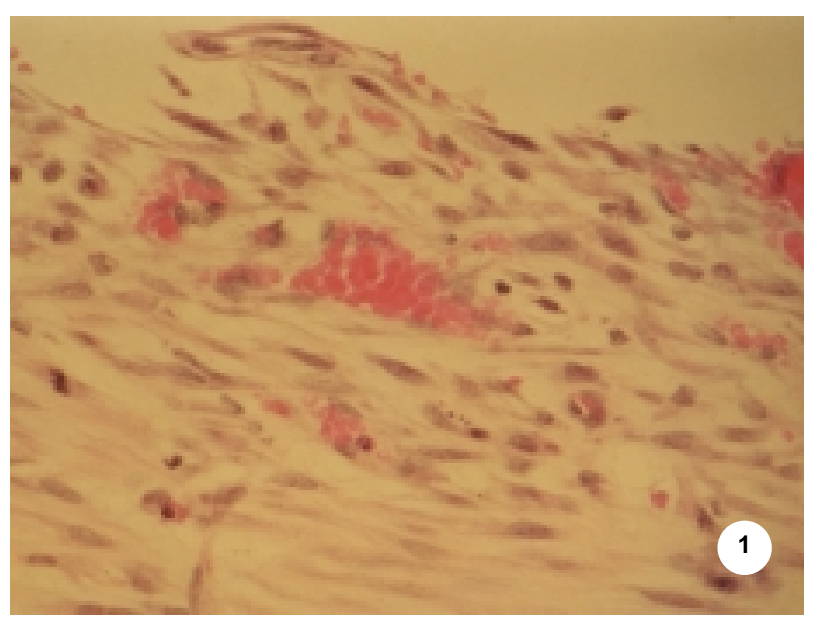

INJ ERTOS 2 SEMANAS

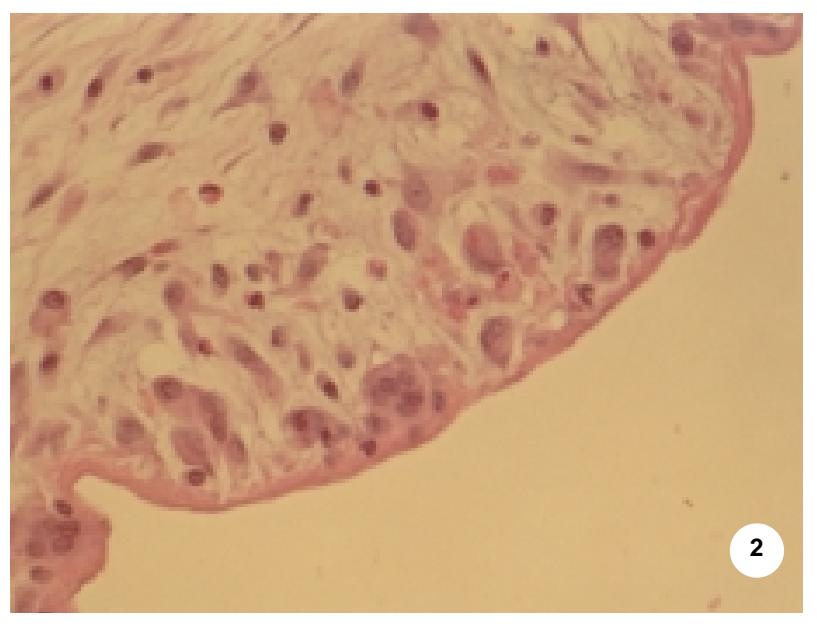

\section{INJ ERTOS 4 SEMANAS}

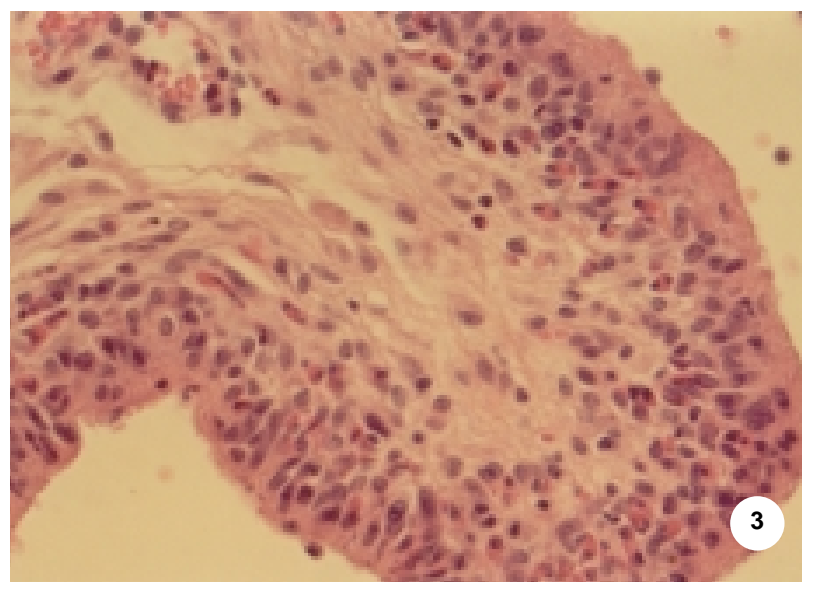

FIGURA 12. 1. Injerto 1 semana. H.E. 25x.; 2. Injerto 2 semanas. H. E. $25 x$; 53. Injerto 4 semanas. H. E. $25 x$. 
potencial de crecimiento con una pobre capacidad de diferenciación, consiguiéndose a lo sumo monocapas de células uroteliales no aptas para trasplantar ${ }^{7-10}$

En 1992 Atala $^{15,16}$ establece las bases para una correcta recolección y cultivo de células uroepiteliales, las cuales siembra sobre polímeros sintéticos biodegradables que posteriormente implanta en el huésped, sentando así las bases de la ingeniería de tejidos dentro de la Urología.

En 1995 Fujiyama $^{21}$ realiza una reconstrucción tridimensional de mucosa vesical, diseñando una submucosa bioartificial compuesta por un gel de colágeno y fibroblastos, otorgando una gran importancia a la misma para el correcto crecimiento y diferenciación de las células uroepiteliales.

En nuestro trabajo aplicamos las técnicas de cultivo celular introducidas por Rheinwald y Green $^{1}$ al urotelio de conejo, diseñando un tejido subepitelial bioartificial a base de un gel de fibrina y fibroblastos que favoreciese el crecimiento y diferenciación de las células epiteliales de conejo. En los cultivos primarios utilizamos una capa de células alimentadoras a base de fibroblastos de ratón letalmente irradiados (3T3), dichas células así tratadas ${ }^{39}$ adquieren la capacidad de estimular el crecimiento, diferenciación y adhesión de las células epiteliales ${ }^{40,41}$, secretan proteínas de matriz extracelular y factores de crecimiento $^{42}$ e inhiben el excesivo sobrecrecimiento fibroblástico ${ }^{43}$.

Dada la extrema fragilidad y la difícil manipulación de estos tejidos debido a su constitución exclusivamente epitelial, dotamos a los mismos de un soporte físico mediante un polímero biodegradable, basándonos en los principios de la ingeniería tisular $36,37,44$, lo que nos permitió manejar los tejidos obtenidos in vitro sin dificultad alguna y a su vez facilitó su posterior injerto ya que la propia biodegradación del polímero provoca una respuesta neoangiogénica en el huésped muy útil en las etapas iniciales del injerto ${ }^{45}$.

Asimismo utilizamos geles de fibrina como soporte para el cultivo de las células uroepiteliales en base a la experiencia de varios autores ${ }^{22-29}$, resultando la misma una proteína escasamente antigénica, capaz de mediar en el crecimiento, migración y diferenciación de las células, sin experimentar fenómenos acusados de retracción como ocurre con el colágeno ${ }^{46}$.

Por otra parte, Staack ${ }^{47}$ pone de manifiesto la importancia de los fibroblastos en el crecimiento y diferenciación de las células uroepiteliales en cultivo, atribuyéndose la acción de los mismos a la secreción de un factor soluble no identificado, probablemente especie y órgano-específico. A su vez éstos inducen una rápida reorganización de la fibrillas que los rodean, las cuales se reorientan en haces paralelos a la superficie de cultivo, por lo que la retracción experimentada por los geles se produce en espesor y no en diámetro, contrariamente a lo que sucede con los geles de colágeno.

Pretendimos demostrar la viabilidad del injerto libre de urotelio autólogo cultivado utilizando como animal de laboratorio el conejo, lo cual nos permitió diseñar un modelo experimental en un animal inmunológicamente intacto, obviando así el uso de animales inmunodeprimidos, y los problemas de rechazo al tratarse de injertos completamente autólogos.

Para el implante se utilizó la técnica descrita por Barrandon ${ }^{38}$, procedimiento que permite estudiar el implante macroscópicamente de manera sencilla y que al parecer disminuye el riesgo de infección o pérdida del injerto, produciendo también una menor retracción del mismo. En nuestro caso dada la consistencia aportada por la malla se ácido poliglicólico al tejido obtenido in vitro, pudimos prescindir de la segunda lámina de silicona utilizada inicialmente por el autor, simplificando, si cabe aún más el procedimiento.

Los tejidos obtenidos mediante las técnicas de cultivo in vitro mostraban un predominio de células de aspecto basal, inmaduras e indiferenciadas, con una débil o nula respuesta a citoqueratinas en parte debido a esa inmadurez y al retraso de la misma sufrido por las células por el cultivo en inmersión ${ }^{21,48}$.

Al estudiar inmunohistoquímicamente las muestras, se observó como los tejidos obtenidos in vitro previo a su injerto y los implantes en etapas iniciales constaban predominantemente de células de aspecto basal, inmaduras con débil o nula inmunotinción para citoqueratinas. En periodos de injerto más largos (2 a 4 semanas), se 
pudo observar un revestimiento epitelial multicapa, de células más maduras, con tinción más positiva para citoqueratinas.

Este hecho ha sido observado por varios autores estableciendo la importancia de las complejas $\mathrm{y}$ desconocidas interacciones entre las células trasplantadas y la matriz extracelular del receptor, mediadas por factores de crecimiento y proteínas de dicha matriz responsables del crecimiento y diferenciación de las células ${ }^{21,22,48-50}$.

En ningún caso se evidenció inmunotinción para colágeno IV o laminina, los cuales persistían negativos incluso en la mucosa de conejo in vivo, lo cual nos indujo a pensar como posible explicación que los clones de anticuerpos utilizados y disponibles comercialmente pudiesen no reaccionar frente a los antígenos presentes en la estructura uroepitelial del conejo, por lo que la negatividad de la inmunotinción para dichos anticuerpos no resultase concluyente en la determinación del desarrollo o no de una membrana basal.

Es preciso señalar que los injertos realizados se encuentran en un lugar heterotópico y que presumiblemente, el desarrollo del epitelio así como el grado de diferenciación celular alcanzado fuese mayor en un injerto más fisiológico, en contacto con el propio urotelio in vivo, gracias a factores de crecimiento o moléculas de matriz extracelular secretadas por el mismo, en su inmensa mayoría desconocidas hasta la fecha ${ }^{51-53}$.

\section{CONCLUSIONES}

Pudimos demostrar que las técnicas de cultivo in vitro de queratinocitos son perfectamente aplicables a otros epitelios como es el urinario, de forma que a partir de un fragmento mínimo de tejido uroepitelial sea posible obtener una gran superficie de urotelio cultivado autólogo mediante la aplicación de las técnicas de cultivo celular in vitro en un plazo de tiempo no superior a 22 23 días.

El "equivalente uroepitelial" diseñado consta de una submucosa bioartificial que estimula el crecimiento y diferenciación celular y de un polímero biodegradable que facilita su manipulación $\mathrm{y}$ favorece su posterior injerto.

$\mathrm{El}$ injerto de urotelio cultivado autólogo en el animal de experimentación inmunológicamente intacto es completamente viable, no objetivándose rechazos ni complicaciones tras diferentes periodos de implante. El estudio inmunomorfohistológico de los injertos confirma su viabilidad y demuestra un uroepitelio mejor conformado y más maduro en los periodos de implante de mayor evolución (4 semanas), si bien no fue posible demostrar el desarrollo de una membrana basal ni en los tejidos obtenidos in vitro, ni en los diferentes periodos de injerto.

Por último señalar que dada la posibilidad de aplicar las técnicas de cultivo celular y de la ingeniería de tejidos al urotelio, quizá la conclusión más importante y esperanzadora es poder demostrar igualmente la viabilidad de dichas técnicas con el urotelio humano; si en un futuro pudiésemos obtener una cantidad importante de uroepitelio autólogo a partir de una pequeña muestra del mismo, posiblemente nos encontrariamos ante un avance más que sustancial de la cirugía reconstructiva del aparato urinario.

Agradecimientos: Quisiera mostrar mi más sincero agradecimiento al personal del Centro Comunitario de Sangre y Tejidos del Principado de Asturias, donde pudimos desarrollar las técnicas de cultivo de tejidos y especialmente a los doctores Alvaro Meana y Sara Gómez, por su inestimable aportación a este trabajo. Agradecer igualmente la colaboración de la Sociedad Cántabra de Urología.

\section{REFERENCIAS}

1. Rheinwald JG, Green H. Serial cultivation of strains of human epidermal keratinocytes: the formation of keratinising colonies from single cells. Cell 1975;6:331-334.

2. Banks-Schlegel S, Green H. Formation of epidermis by serially cultivated human epidermal cells transplanted as an epithelium to athymic mice. Transplantation 1980; 29(4):308-311.

3. Southgate J, Williams HK, Tredjdosiewic LK, Hodges GM. Primary culture of human oral epithelial cells: growth requirements and expression of differentiated characteristics. Lab Inves 1987:56(2):211-233.

4. De Luca M, Albanesse E, Megna M, Cancedda R, Mangiante PE, Cadoni A, Franci AT. Evidence that human oral epithelium reconstituted in vitro and transplanted onto patients with defects in the oral mucosa retains properties of the original donor site. Transplantation 1990;50(3):454-459.

5. Ueda M, Hata K, Sumi Y, Mizuno H, Niimi A. Peri-implant soft tissue management through use of cultured mucosal epithelium. O Surg. O Med. O Pathol. O Radiol. Endodont 1998;86:393-400.

6. Hata K, Kagami H, Ueda M, Torii S, Matsuyama M. The characterics of cultured mucosal cell sheet as a material for grafting; comparison with cultured epidermal cell sheet. Ann Plast Surg 1995;34:530-538.

7. Elliot AY, Stein N, Fraley EF. Technique for cultivation of transicional epithelium from mammaliam urinary bladder. In vitro 1975;11:251 254.

8. CHLAPOWSKI F.J., HAYNES L. The growth and differentiation of transitional epithelium in vitro. J Cell Biol 1979;83:605-614. 
9. Pauli BU, Anderson SN, Memoli VA, Kuettner KE. The isolation and characterization in vitro of normal epithelial cells, endothelial cells and fibroblasts from rat urinary bladder. Tissue Cell 1980;12:419-435.

10. Messing EM, Fahey JL, Dekernion JB, Bhutta S, Fahey J. Serum free medium for the in vitro growth normal and malignant urinary bladder epithelial cells. Cancer Res 1982;42:2392-2397.

11. Reznikoff CA, Johnson MD, Norback DH, Bryan GT. Growth and characterization of normal human urothelium in vitro. In Vitro 1983; 19:326-343.

12. Schmidt WW, Messing EM, Reznikoff CA. Cultures of normal human urothelial cells from ureters of perfused cadaver transplant kidneys. J Urol 1984;132:1262-1264.

13. Romagnoli G, De Luca M, Faranda F, Bandelloni R, Franzi AT, Cataliotti F, Cancedda R. Treatment of posterior hypospadias by the autologous graft of cultured urethral epithelium. N Eng J Med 1990; 323:527-530.

14. Romagnoli G, De Luca M, Faranda F, Franzi AT, Cancedda R. One-step treatment of proximal hypospadias by the autologous graft of cultured urethral epithelium. J Urol 1993;150:1204-1207.

15. Atala A, Vacanti JP, Peters CA, Mandell J, Retik AB, Freeman MR. Formation of urothelial structures in vivo from dissociated cells attached to biodegradable polymer scaffolds in vitro. J Urol 1992;148:658 662.

16. Atala A, Freeman MR, Vacanti JP, Shepard J, Retik AB. Implantation in vivo and retrieval of artificial structures consisting of rabbit and human urothelium and human bladder muscle. J Urol 1993;150:608612.

17. Vacanti JP, Langer R. Tissue engineering: the design and fabrication of living replacement devices for surgical reconstruction and transplantation. Lancet 1999;354: 32-34.

18. Langer R, Vacanti JP. Tissue engineering: The challenges ahead. Sci Am 1999;280(4):86-89.

19. Machluf M, Atala A. Tissue engineering: Emerging concepts. Graft 1998; 1:31-37.

20. Kaihara S, Vacanti JP. Tissue engineering. Toward new solutions for transplantation and reconstructive surgery. Arch Surg 1999;134: 1184-1188.

21. Fujiyama C, Masaki Z, Sugihara H. Reconstruction of the urinary bladder mucosa in three-dimensional collagen gel culture: fibroblastextracellular matrix interactions on the differentiation of transitional epithelial cells. J. Urol 1995;153:2060-2067.

22. Wechselberger G, Schoeller T, Stenzl A, Ninkovic M, Lille S, Russell RC Fibrin glue as delivery vehicle for autologous urothelial cells transplantation onto a prefabricated pouch. J Urol 1998;160:583-586.

23. Wechselberger G, Schoeller T, Roth AC, Lille S, Russell RC. Transplantation of autologous cultured urothelium cells onto a prefabricated capsule in rats. En Stark G.B., Horch A.C., Tanczos E. Biological matrices and tissue reconstruction. Springer-Verlag 1998; 125-134

24. Wechselberger G, Bauer T, Meirer R, Piza-Katzer H, Lille S, Russe RC, Schoeller T. Muscle prelamination with urothelial cell cultures via fibrin glue in rats. Tissue Eng 2001; 7(2):153-159.

25. Schoeller T, Lille S, Stenz A, et al. Bladder reconstruction using a prevascularized capsular tissue seeded with urothelial cells. J Urol 2001 165:980-985.

26. Schoeller T, Wechselberger G, Lyons S, Otto A, Russell RC. Urothelial cell culture behavior in fibrin glue compared to conventional culture medium. En Stark GB, Horch AC, Tanczos E. Biological matrices and tissue reconstruction. Springer-Verlag 1998;125-134.

27. Schoeller T, Lille S, Bauer T, Piza-Katzer H, Wechselberger G. Gracilis muscle flap with a tissue engineered lining for experimental bladder wall reconstruction. BJU Int 2001; 88(1):104-109.

28. Schaefer BM, Back W, Kramer MD, Schober C, Waag KL, Lorenz C. Autologous transplantation of urothelium into demucosalized gastrointestinal segments. En Stark GB, Horch AC, Tanczos E. Biological matrices and tissue reconstruction. Springer-Verlag 1998;125-134.

29. Bach AD, Bannasch H, Galla TJ, Bitnner KM, Stark GB. Fibrin glue as matrix for cultured autologous urothelial cells in urethral reconstruction. Tissue Engineering 2001;7:45-53.

30. Atala A. Tissue engineering in urologic surgery. Urol Clin North Am 1998;25:39-50.
31. Atala A. Future perspectives in reconstructive surgery using tissue engineering. Urol Clin North Am 1999;26: 157-165.

32. Atala A. Construction of artificial organs and tissues using autologous cells. A.U.A. Update Series 2000;19(16):122-127.

33. Atala A. Regenerative medicine and urology. B.J.U. Int 2003;92 (suppl.1):58-67.

34. Atala A. Tissue engineering, stem cells, and cloning for the regeneration of urologic organs. Clin Plast Surg 2003; 30(4):649-667.

35. Atala A. Tissue engineering perspectives for reconstructive surgery. En Walsh PC, Retik AB, Vaughan ED, Wein AJ. Editores. Campbell's Urology. 8 ${ }^{\mathrm{a}}$ Ed. Philadelphia. Ed. Saunders. 2002;2593-2622.

36. Pariente JL, Kim BS, Atala A. In vitro biocompatibility assessment of naturally derived and synthetic biomaterials using normal human urothelial cells. J Biomed. Mater Res 2001;55(1):33-39.

37. Pachence JM, Kohn J. Biodegradable polymers. En Lanza RP, Langer $\mathrm{R}$, Vacanti JP editores. Principles of tissue engineering. $2^{\mathrm{a}}$ edición. San Diego, California. Academic Press 2000;263-277.

38. Barrandon Y, Li V, Green H. New techniques for the grafting of human epidermal cells onto athymic animals. J Invest Dermatol 1988;91:315318.

39. Navsaria HA, Sexton C, Bouvard V, Leigh IM. Growth of keratinocytes with a 3T3 feeder layer: basic techniques. En Leigh IM, Watt FM directores. Keratinocyte Methods Cambridge University Press 1994;2-12.

40. Rheinwald JG. Serial cultivation of normal human keratinocytes. Methods in cell biology 1980;21:229-254.

41. Alitalo K, Kuismanen E, Myllilä R, Kiistala U, Asko-Seljavaara S, Vaheri A. Extracelular matrix proteins of human epidermal keratinocytes and feeder 3T3 cells. J Cell Biol 1982;94:497-505.

42. Green H. Cyclic AMP in relation to prolifertion of the epidermal cell. Cell 1978;15:801-811.

43. Freeman AE, Igel HJ, Herrman BJ. Growth and characterization of human skin epithelial cells cultures. In Vitro 1976;12:352-362.

44. Pariente JL, Bordenave L, Bareille R, Baquey CH., Le Guillou M. Cultured differenciated human urothelial cells in the biomaterials field. Biomaterials 2000;21:835-839.

45. Kim BS, Baez CE, Atala A. Biomaterials for tissue engineering. World J Urol 2000;18:2-9.

46. Bach AD, Bannasch H, Galla TJ, Bitnner KM, Stark GB. Fibrin glue as matrix for cultured autologous urothelial cells in urethral reconstruction. Tissue Engineering 2001;7:45-53.

47. Staack A, Alexander T, Merguerian P, Terris MK. Organ and species specificity in the stimulation of transitional epithelial cell growth by fibroblasts. Eur Urol 2001;39(4): 471-477.

48. Ueda M, Ebata K, Kaneda T. In vitro fabrication of bioartificial mucosa for reconstitution of oral mucosa: basic research and clinical application. Ann Plast Surg 1991:27:540-549.

49. Tobin MS, Freeman MR, Atala A. Maturational response of normal human urothelial cells in culture is dependent on extracellular matrix and serum additives. Surg Forum 1994;45:786-789.

50. Martins-Green M. Dynamics of cell-extracellular matrix interactions. En Lanza R.P., Langer R., Vacanti J.P. editores. Principles of tissue engineering. $2^{\underline{a}}$ edición. San Diego, California. Academic Press 2000; 33-48.

51. Lorenz C, Maier-Reif K, Back W, Hohl HP, Waag KL. Cultured urothelium in sheep bladder augmentation. Pediatr Surg Int 1996;11:456 461 .

52. Disandro M, Baskin L, Li Y, Hayward S, Cunha G. Mesenchimal-epithelial interactions in bladder smooth muscle development: epithelia specificity. Pediatrics 1997;100:11(suppl.).

53. Baskin L, Disandro M, Li Y, Li W, Hayward S, Cunha G. Mesenchimalepithelial interactions in bladder smooth muscle development: effects of the local tissue environment. J Urol 2001;165:1283-1288.

\footnotetext{
Dr. E. de Diego Rodríguez

Miguel de Unamuno, 6 - 5ㅇ B

39012 Santander (Cantabria)
}

(Trabajo recibido el 18 junio de 2004) 